\title{
The US Unemployment Insurance Scheme: A Model for the EU?
}

The system of unemployment insurance (UI) used in the United States has often been cited as a model for Europe. The American model illustrates that it is possible to create and maintain a UI system based on federal-state co-financing that intensifies during economic crises and thus reinforces protection and stabilisation. Central requirements and conditional funding can improve the aggregate protection and stabilisation capacity of the system. However, the architecture of the US system financially incentivises states to organise retrenchment of their own efforts for UI, which in turn leads to a divergence of benefit generosity and coverage levels. During the Great Recession, the federal government mitigated these incentives for retrenchment through minimum requirements attached to federal financial intervention. With regards to the European unemployment re-insurance system debate, the US experience implies both positive and encourageing conclusions and cautionary lessons.

In 2012, a major report on the future of the Economic and Monetary Union (EMU) suggested creating a macroeconomic shock absorption mechanism. One proposed option is a fiscal capacity that would act as a "complement or partial substitute to national unemployment insurance systems". Since then, the idea of an EMU-level 'unemployment re-insurance' has garnered significant atten-

(C) The Author(s) 2019. Open Access: This article is distributed under the terms of the Creative Commons Attribution 4.0 International License (https://creativecommons.org/licenses/by/4.0/), which permits unrestricted use, distribution, and reproduction in any medium, provided you give appropriate credit to the original author(s) and the source, provide a link to the Creative Commons license, and indicate if changes were made.

1 H. Van Rompuy, J.M. Barroso, J. Juncker, M. Draghi: Towards a genuine economic and monetary union, Brussels 2012, p. 12.

Christiaan Luigjes, University of Amsterdam, The Netherlands.

Georg Fischer, Vienna Institute for International Economic Studies, Austria.

Frank Vandenbroucke, University of Amsterdam, The Netherlands. tion. $^{2}$ The French and German Finance Ministers Bruno Le Maire and Olaf Scholz, respectively, agreed to work on a reinsurance scheme and in July 2018, ECB President Mario Draghi declared such efforts important for the future of the euro area in a hearing in the European Parliament. ${ }^{3}$ In her agenda for Europe, European Commission's President Ursula von der Leyen promises to propose a European Unemployment Benefit Reinsurance Scheme. ${ }^{4}$ Opinion research shows public support for cross-border risk sharing when unemployment hits Member States. But this support crucially depends on

2 See, among others, X. Ragot: Civiliser le Capitalisme. Crise du libéralisme européen et retour du politique, Fayard 2019; European Commission: Reflection Paper on the Deepening of the Economic and Monetary Union, 31 May 2017 (COM(2017) 291); N. Carnot, M. Kizior, G. Mourre: Fiscal stabilization in the Euro-Area: a simulation exercise, CEB Working Paper, 2017/025; L. Andor, S. Dullien, H.X. Jara, H. Sutherland, D. Gros: Designing a European unemployment insurance scheme; in: Intereconomics, Vol. 49, No. 4, 2014, pp. 184-203; M. Beblavy, K. Lenaerts: Feasibility and Added Value of a European Unemployment Benefit Scheme, CEPS 2017; S. Dullien: A European unemployment benefit scheme: How to provide for more stability in the euro zone, Gütersloh 2014, Bertelsmann Stiftung.

3 M. Draghi: Answer to a question by MEP Weizsäcker: EP Economic and Finance Committee, 9 July 2018; French government: French German roadmap for the Euro Area, 2018.

4 U. Von der Leyen: My agenda for Europe: Political Guidelines for the Next European Commission 2019-2024, https://ec.europa.eu/ commission/interim_en, 2019, p. 10. 
the scheme's adequacy, job search and training features. ${ }^{5}$ In this paper, we discuss the American UI system and identify relevant lessons learned. ${ }^{6}$

\section{Unemployment insurance to absorb macroeconomic shocks}

The reference to UI in debates about the need for a Eurozone-level macroeconomic shock absorption mechanism is not a coincidence. Ul supports the purchasing power of citizens in an economic downturn and is therefore an automatic stabiliser par excellence. Existing monetary unions either opt for a downright centralisation of UI (historically, Canada or Germany) or they demand some convergence in the organisation of $\mathrm{UI}$ and provide re-insurance when the need is high (the US). This is rational for two reasons: First, risk pooling enhances resilience against asymmetric shocks in a monetary union and has been the main argument in support of automatic fiscal stabilisers ${ }^{7}$ allowing for interregional smoothing of economic shocks. ${ }^{8}$

Second, even when shocks are completely symmetric, national insurance systems create a positive externality; a country that properly insures itself also helps its neighbours. Therefore, it is in the common interest of all members to organise an effective stabilisation capacity. Monetary unions are faced with a collective action problem: UI increases labour costs, and without some coordination, competitive pressure militates against the organisation of sufficiently generous UI. The effectiveness of the stabilisation capacity of EMU Member States depends on a cluster of policy principles: adequate unemployment benefits, sufficient coverage and effective activation of unemployed individuals. The implementation of these policy principles in each Member

5 F. Vandenbroucke, B. Burgoon, T. Kuhn, F. Nicoli, S. Sacchi, D. van der Duin, S. Hegewald: Risk Sharing When Unemployment Hits: How Policy Design Influences Citizen Support For European Unemployment Risk Sharing (EURS), AISSR Policy Report 1, December 2018.

6 This is a short version of a longer working paper that includes a formal analysis of incentives, disincentives and trade-offs created by a two level scheme of funding and regulating including through graphical illustration; C. Luigjes, G. Fischer, F. Vandenbroucke: The design of a European unemployment (re)insurance scheme: lessons from US experience, ACES Research Paper 2019/06.

7 The notion of 'asymmetric shocks' is conceptualized broadly here: a shock that is symmetric in origin may play out differently in individual countries.

8 There is consensus that Eurozone-level interregional and intertemporal smoothing must be combined: since the business cycles of EU Member States are partly synchronized, economic shocks are partly symmetric. See P. De Grauwe, Y. Ji: Boom, Busts and the Governance of the Eurozone, in: F. Vandenbroucke, C. Barnard, G. De Baere (eds.): A European Social Union after the Crisis, Cambridge 2017, Cambridge University Press, pp. 160-191; M. Dolls, C. Fuest, D. Neumann, A. Peichl: An unemployment insurance scheme for the euro area? A comparison of different alternatives using microdata, in: International Tax and Public Finance, Vol. 1, 2018.
State is of common concern. One of the strongest arguments in favour of EU support for national UI schemes is that it would contribute to the national implementation of these domestic principles. Conversely, these stability-supporting domestic principles become a fortiori imperative when cross-border risk sharing is organised: national governments would not agree to support each other's UI system if they could not guarantee that their national system functions adequately.

Thus, our argument is that cross-border risk sharing enhances the stability of the Eurozone and, moreover, that the quality of domestic policies and cross-border risk sharing are intrinsically related. However, it is not self-evident that cross-border risk sharing by itself enhances the quality of domestic policies. Two caveats need to be borne in mind, which we illustrate here using the American experience. The first concerns the risk of retrenchment at the state level: the commitment of a supra-state authority to support national UI systems may induce them to retrench their own efforts depending on the design of the supra-national commitment. Second, this dynamic of retrenchment might lead to divergence between the states' own social policies. A reduction in the state-level effort for macroeconomic stabilisation via UI when the federal level commits itself to contribute to macroeconomic stabilisation via UI (our first caveat), is to some extent unavoidable: a (partial) federal take-over and thus a diminished role for the states can even be the explicit purpose of a federal intervention. However, the federal commitment should not lead to a structural retrenchment of state systems and/or to divergence across states. ${ }^{9}$

\section{History and outline of UI in the US}

The American UI system was created in 1935 in the wake of the Great Depression and was intended as a partial replacement of income for the unemployed and as a tool to stabilise the economy and prevent a breakdown of labour standards. ${ }^{10}$ Although UI made economic sense, states feared interstate tax competition: If a state created such a scheme individually, businesses might relocate to another state without UI. The federal government could overcome this collective action problem, but it had to consider the constitutional autonomy of states. Balancing these concerns, the federal

9 There is a third and important caveat, concerning 'institutional moral hazard'. If the cost of a risk run by states (the cost of unemployment) is covered by an insuror (the supra-state level), the states' effort to reduce this risk might diminish. We do not discuss such institutional moral hazard here, since the US experience does not illustrate it. See F. Vandenbroucke, C. Luigjes, D. Wood, K. Lievens: Institutional moral hazard in the multi-tiered regulation of unemployment and social assistance benefits and activation, CEPS Special Report 137, Brussels 2016, Centre for European Policy Studies.

10 D.N. Price: Unemployment Insurance, Then and Now 1935-85, in: Social Security Bulletin, Vol. 48, No. 10, October 1985, pp. 22-32. 
government provided financial incentives for all states to create UI schemes following federal requirements. If states complied with those requirements, the federal government would finance their respective administration through a federal payroll tax and reduce businesses' federal tax rate by $90 \%$. The federal requirements concern mostly the administration and the financing of state systems while states have almost complete autonomy regarding eligibility criteria and generosity. Under normal circumstances, states are required to finance benefits from their own UI trust fund. When state UI trust funds are depleted, states can receive a federal advance to pay their UI obligations. These advances, in turn, have to be repaid with interest. If a state runs consecutive annual trust fund deficits, the federal government will charge employers in that state a federal penalty tax.

Since 1970, federal law provides an automatic extension of the maximum duration of benefits which is triggered when unemployment in a given state rises above a certain threshold this extension is equally financed by the federal government and the states. Congress can adopt ad hoc fully federally funded emergency extensions in an economic downturn. The extension of benefits, (partially) financed by the federal budget, follows the logic of a complementary insurance since it adds to the existing regular state UI benefits.

\section{Functioning of the American UI system}

The basic set up of the American UI system allows states to alter important parameters of their scheme while interstate tax competition has, to some degree, been overcome. Macroeconomic stabilisation is ensured by federal funding for the payment of benefits in crisis periods. During the recent crisis, however, the American system exposed weaknesses that have been building up in recent decades. ${ }^{11}$ First, interstate tax competition re-emerged and resulted in retrenchment of UI schemes and inadequate funding in multiple states. States finance regular UI benefits predominantly through employers' taxes while they are simultaneously lobbied by employers to lower tax rates. To cope with reduced revenues, a number of states reduced generosity and/or tightened eligibility. Some states simply acquiesced to have near-insolvent UI trust funds, a situation the UI system was designed to pre-empt. The state unemployment taxes are required to have a taxable wage base that is at least equal to the federal taxable wage base that was historically set at a level deemed sufficient to prevent a race to the bottom. The federal tax base, however, has not changed since 1983 and is therefore increasingly inadequate. As the federal penaltytax on employers in states that run consecutive trust fund

11 G. Fischer: The US unemployment insurance, a federal-state partnership: Relevance for reflections at the European level, IZA Policy Paper 129, 2017. deficits are calculated as a share of this federal tax base, this penalty tax has become ineffective.

Second, the triggers on which the system of extended benefits relies have proven to be unreliable. The original triggers are based on the Insured Unemployment Rate (IUR), which measures the number of unemployed who receive unemployment benefits as a share of the jobs covered by UI. The IUR is affected by eligibility criteria that states determine themselves. Some states have tightened eligibility over the years and the IUR became increasingly insensitive to actual unemployment trends measured by the Total Unemployment Rate (TUR). ${ }^{12}$ Consequently, during economic downturns extended benefits often were not triggered. ${ }^{13}$ In addition, extensions follow the respective state eligibility and duration provisions. Stricter rules and lower recipiency rates mean that workers benefit less from federal funds. The reasons for tightening eligibility criteria include a (re-emerged) interstate tax competition and/or states' lack of will to fund extended benefits, although they only finance half of those. There is also an ideological aversion to social benefits in general.

As a result of these developments, divergence between state UI programmes increased after the recent crisis. In the 1930s, state UI schemes were fairly homogeneous but as a result of these developments, schemes started to diverge increasingly after the recent crisis. ${ }^{14}$ Today, state schemes vary somewhat in terms of generosity and widely in terms of eligibility criteria. ${ }^{15}$

Although these weaknesses were noted decades before the Great Recession, ${ }^{16}$ the federal government was reluctant to take action. Thus, when the Great Recession hit, it was confronted with 36 insolvent state funds, ${ }^{17}$ weak levels of protection for the unemployed in many states and a resulting low macroeconomic stabilisation potential. In response,

12 C.J. O'Leary, S. Wandner: Unemployment insurance reform: Evidence-based policy recommendations, in: S. Wandner (ed.): Unemployment insurance reform: Fixing A broken system, Kalamazoo, Michigan 2018, W.E. Upjohn Institute for Employment Research, pp. 136-137.

13 C.J. O'Leary, B.S. Barnow: Lessons from the American federalstate unemployment insurance for a European unemployment benefit system, Upjohn Institute Working Paper No. 16-264, 2016, pp. 13-14.

14 S. Dullien, op. cit., p. 44.

15 See G. Fischer, op. cit.; C.J. O'Leary, B.S. Barnow, op. cit.; K. Lenaerts, F. Paquier, S. Simonetta: Unemployment insurance in America: A model for Europe? CEPS Policy Insights, 23 June 2017, pp. 1-22.

16 ACUC: Collected findings and recommendations: 1994-1996, Washington DC 1996, Advisory Council on Unemployment Compensation.

17 This was due to the severity of the crisis but also because funding levels were at their lowest point in almost two decades; see S. Simonetta: UI reform proposals in the fiscal year 2017 Obama budget request, in: S. Wandner (ed.): Unemployment insurance reform: Fixing a broken system, Kalamazoo, Michigan 2018, pp. 23-64, W.E. Upjohn Institute for Employment Research. 
the federal government took extraordinary measures. ${ }^{18}$ It financed $100 \%$ (instead of $50 \%$ ) of extended benefits if states adopted triggers based on the TUR (actual unemployment) rather than the IUR. Congress legislated additional federally financed emergency benefits, further extending the benefit duration to a maximum of 99 weeks. In return, states had to accept a 'non-reduction rule' (states could not lower their replacement rates) and less restrictive eligibility so that more jobless workers would receive benefits thereby increasing recipiency rates. Additionally, the federal government made grants available for the 'modernisation' of state UI schemes. States could use these grants for expanding eligibility, introducing short-term-work compensation and updating old IT-systems. The federal share of total UI benefit costs reached a historic high in $2011 . .^{19}$ In effect, during the Great Recession the federal government overcompensated the retrenchment of states' UI schemes.

All new federal requirements were tied to the extraordinary federal funds and expired January 2014. Since 2014, a number of states returned to the IUR triggers, abandoned modernisation efforts and/or retrenched their UI schemes. Eight states exploited a loophole in the nonreduction rule to reduce the standard UI duration during the crisis. Importantly, mostly states with the more robust UI systems maintained TUR triggers, used the modernisation grants and kept systemic improvements. Contrarily, states that revoked the TUR triggers, organised further retrenchment and did not utilise modernisation grants were generally those with less generous programmes. So the pre-crisis diversity in state $\mathrm{Ul}$ programmes was temporarily muted but increased again post-crisis. Figure 1 shows the evolution of diversity in terms of recipiency rates and also the effect of federal requirements to expand eligibility criteria during the crisis and of the extension of duration. This was only possible because the federal government could fund the extensions through an increase in public debt which states cannot do. The post-crisis divergence is unsurprising given the design features of the American system and the resulting tensions briefly revisited in this section. ${ }^{20}$

In 2016, the outgoing Obama administration proposed changes, such as increasing the federal tax base by almost $600 \%$, expanding eligibility, introducing a nationwide floor for the maximum benefit duration set by

18 W. Vroman, S. Woodbury: Financing unemployment insurance, in: National Tax Journal, Vol. 67, No. 1, 2014, pp. 253-268.

19 C.J. O'Leary: A changing federal-state balance in unemployment insurance? in: Employment Research, Vol. 20, No. 1, 2013, pp. 1-4.

20 C. Luigjes, G. Fischer, F. Vandenbroucke, op. cit., formally demonstrate how the features of complementary insurance can lead to such results.
Figure 1

Recipiency rate and divergence across states from 1999-2015

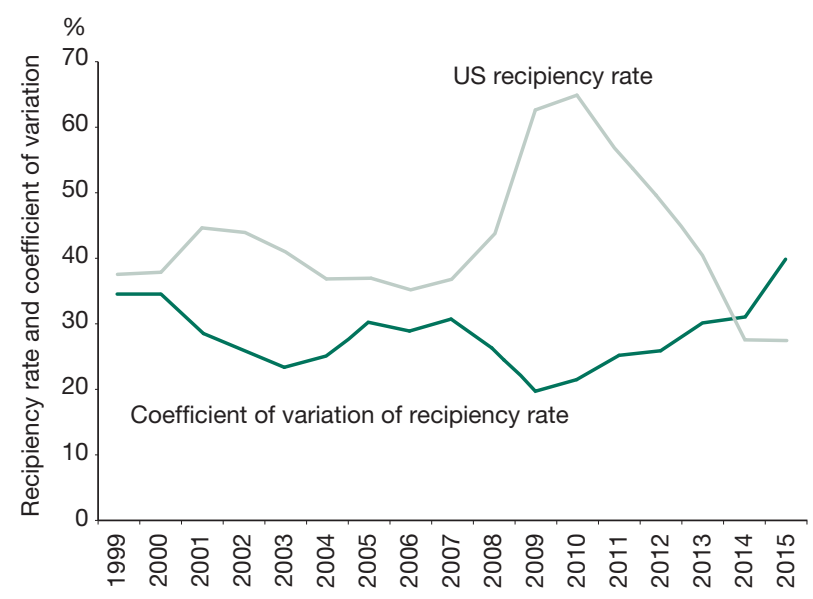

Source: Unemployment Insurance Data Summary, Employment and Training Administration, Department of Labor.

state $^{21}$ and a host of additional nationwide requirements. ${ }^{22}$ Many experts have cited the need for federal reforms, most urgently regarding recipiency rates and the tax base. ${ }^{23}$ But changes were not adopted.

\section{Lessons from the American experience}

We caution against an oversimplified comparison between American $\mathrm{UI}$ and a possible European re-insurance. The origins of the US system are distinct: In 1935, schemes had to be created from scratch; and during their inception state schemes were relatively homogenous. In contrast, UI programmes of EU Member States are well-established, often predating the EU. While the main method for the US federal government to regulate $\mathrm{UI}$ is its fiscal capacity through funding and taxation, the EU neither has the same level of resources nor does it have the mandate to levy taxes. The process and institutions for decision-making in the EU and US are very different. The US emergency benefits that were so important for macroeconomic stabilisation were approved by Congress on an ad hoc basis. European decision-making is less agile. During the European sovereign debt crisis, it proved near

21 A floor limits the possibility of states to lower the maximum duration below a certain number of weeks.

22 S. Simonetta, op. cit.

23 Most prominently S. Wandner: Unemployment insurance reform: Fixing a broken system, Kalamazoo, Michigan, W.E. Upjohn Institute for Employment Research, 2018. 
impossible to reach consensus about ad hoc crisis resolution measures.

There are, however, positive lessons to draw from the American UI system. First, the US experience shows that it is possible to create and maintain a UI system based on federal-state co-financing that intensifies during economic crises. Second, the federal-state relationship has adjusted over time, for example through the creation of extended and emergency benefits. Third, the influx of federal dollars buoyed state UI schemes during multiple recessions and bolstered their macroeconomic stabilisation effects based on the capacity of the federal government to fund through public debt. Fourth, the genesis of the US UI shows that conditionality, i.e. imposing requirements in return for federal funds, can work. It proved an effective way to create relatively homogenous state programmes in the first place. And federal interventions during the recent crisis showed the potential of conditionality. However, the divergence of state programmes returned after federal funds stopped. This 'glass half-full or half-empty' situation in terms of the effectiveness of limited conditions and optional grants is relevant for EU policies that emphasise conditional funding.

There are also cautionary lessons to be drawn from the US experience. The architecture of the US system incentivises states to retrench their UI programmes, in both the duration of the benefits and the funding of the systems. Concerns about wage-cost competitiveness incentivise retrenchment in the funding of the state systems, which relies on employer contributions. Historically, the US system relied on a combination of financing requirements and fiscal incentives to prevent a race to the bottom and to promote sustainable funding. The fiscal incentives for states, however, steadily diminished because the federal tax base - which determines the actual strength of these incentives - has remained unchanged since 1983. Thus, the US now lacks both an effective fiscal incentive structure and a comprehensive system of federal minimum requirements.

Therefore, the strong upward trend of the federal share of UI financing in recession years since 1958 is unsurprising. ${ }^{24}$ State retrenchment negatively impacts stabilisation effects of the UI system, which has to be compensated by the federal government. The first general conclusion from this is that the potential for such perverse incentives needs to be carefully considered in the design of any EMU-level (re-)insurance scheme, i.e. schemes that are based on a 'top-up' of national benefit systems and

24 C.J. O'Leary, op. cit. schemes that have the potential to 'accommodate' suboptimal funding policies should be avoided.

Second, the diversity that emerged across US states reminds us that together with the incentive structure of the federal-state partnership, differences in attitudes of state policy-makers concerning unemployment strongly impact the quality of protection of stabilisation. The EU should define a common approach to the protection of the unemployed in particular as UI systems in Europe are already fairly diverse.

Third, despite historical examples of US federal reforms, recent experience shows that it is difficult to make nationwide structural, lasting changes. The erosion of the American model is not just due to state behaviour, but it is also the result of a lack of federal action. This experience is highly relevant since re-insurance schemes will typically be effective in periods of rising and high unemployment, hence moments that are unsuitable for imposing new and/or stricter conditions. Furthermore, it emphasises the need for well-developed, minimum requirements at the outset of any European re-insurance. Although defining and implementing pan-European minimum requirements concerning the quality of $\mathrm{UI}$ and activation policies undoubtedly is a challenge - not least due to the heavy decision making process in the EU - one should not be unduly pessimistic about this. Over the years, the EU has acquired extensive expertise with the definition and implementation of minimum requirements, via hard and soft law and benchmarking, including the domain of employment promotion policies and employment protection. The European Pillar of Social Rights constitutes a useful general framework for developing minimum requirements regarding $\mathrm{UI}$ and activation policies.

Fourth, one should avoid the need for a succession of ad hoc measures to maintain the integrity of the system in the long run. The concept of a taxable wage base is specific to the US context, but it illustrates the point that the underlying fiscal parameters of an unemployment (re-)insurance must not be vulnerable to erosion; otherwise, the long-run integrity of the system depends on difficult-to-implement new reforms, which might not happen altogether. Also, these fiscal parameters should not be subject to Member State manipulation, as with the triggers for extended benefits in the US. Most proposals for a European unemployment re-insurance avoid such design problems, for instance, by linking the funding to Member States' GDP. There are good reasons to pursue that direction. In short, the American UI experience is relevant and holds valuable lessons, but it should not be considered a blueprint. 